\title{
Application of Ionic Liquid as a Green Solvent for Polyphenolics Content Extraction of Peperomia pellucida (L) Kunth Herb
}

\author{
Islamudin Ahmad ${ }^{1,2 *}$, Arry Yanuar' ${ }^{2}$, Kamarza Mulia $^{3}$, Abdul Mun'im $^{2 *}$ \\ ${ }^{1}$ Department of Pharmaceutical Sciences, Faculty of Pharmacy, Mulawarman University, Samarinda 75119 East Kalimantan, INDONESIA. \\ ${ }^{2}$ Department of Pharmaceutical Sciences, Faculty of Pharmacy, Universitas Indonesia, Depok 16424 West Java, INDONESIA. \\ ${ }^{3}$ Department of Chemical Engineering, Faculty of Engineering, Universitas Indonesia, Depok 16424 West Java, INDONESIA.
}

\begin{abstract}
Objective: The aims of the study was to explore the application effect of ionic liquid as a green solvent in the polyphenolics content extraction from Peperomia pellucida (L.) Kunth herbs using 1-butyl-3-methyl imidazolium bromide ([BMIM]Br) and 1-butyl-3-methyl imidazolium chloride ([BMIM]Cl). Methods: The polyphenolics content extraction was performed by using the ionic liquid based microwave-assisted extraction (IL-MAE) method with some extraction parameters, including extraction time, microwave power, ratio liquid-solid, and ionic liquid concentration. The yields of total polyphenolic content were examined using a microplate reader 96 well method, and the extraction mechanism was analyzed using scanning electron microscopy (SEM). Results: The results showed that the effect of ionic liquid on the yield of total polyphenolics content, including 18.287 $\mu \mathrm{g} \mathrm{GAE/g}$ $(0.7 \mathrm{~mol} / / \mathrm{l}$ [BMIM]Cl concentration, $14 \mathrm{ml} / \mathrm{l}$ liquid-solid ratio, and 270 Watts microwave power for 10 minutes), and $15.734 \mu \mathrm{g}$ GAE/g $(0.7 \mathrm{~mol} / \mathrm{l}$ [BMIM] $\mathrm{Br}$ concentration, $14 \mathrm{ml} / \mathrm{l}$ liquid-solid ratio, and 270 Watts microwave power for 15 minutes), whereas the SEM demonstrated the extraction mechanism with significant physical changes in matrix sample after treatment using different solvents. Conclusion: Application of green chemistry principles
\end{abstract}

using an ionic liquid as a green solvent for the polyphenolic extraction of $P$. pellucida herbs to be rapid, easy, and efficient.

Key words: Peperomia pellucida (L.) Kunth, Total polyphenolic content, Ionic liquid-based microwave-assisted extraction, 1-butyl-3-methyl imidazolium bromide, 1-butyl-3-methyl imidazolium chloride.

Key message: Application of ionic liquid as a green solvent combined with microwave assisted extraction for the polyphenolics extraction of Peperomia pellucida (L.) Kunth herb to be rapid, easy, and efficient.

\section{Correspondence}

Islamudin Ahmad \& Abdul Mun'im, Department of Pharmaceutical Sciences, Faculty of Pharmacy, Mulawarman University, Samarinda 75119 East Kalimantan, INDONESIA \& Department of Pharmaceutical Sciences, Faculty of Pharmacy, Universitas Indonesia, Depok 16424 West Java, INDONESIA.

Phone: +6281-342-205-060

Email: islamudinahmad@farmasi.unmul.ac.id; abdul.munim61@ui.ac.id DOI: 10.5530/jyp.2017.9.95

\section{INTRODUCTION}

Peperomia pellucida (L.) Kunth herbs is a Piperaceae family and can be found in wet environments throughout the territory of Indonesia. It is traditionally used as an analgesic, anti-hyperuricemic, anti-diabetes mellitus, and antihypertension. ${ }^{1}$ Some studies have reported the pharmacological properties of this plant such as antihyperglycemic oxidative stress, dyslipidemia in diabetic rats, ${ }^{2}$ anti-inflammatory, analgesic activity, ${ }^{3}$ and antihypertension. ${ }^{4}$ Also, reported the content of secondary metabolites including essential oil, terpenes, alkaloid, phenols, and flavonoids. ${ }^{5}$ Some polyphenolic compounds such as quercetin, ${ }^{4}$ chromenes, ${ }^{6}$ dillapiole, ${ }^{7}$ xanthone patulosida $\mathrm{A},{ }^{8}$ peperomins, ${ }^{9}$ and pellucidin $\mathrm{A}^{10}$ were isolated.

P. pellucida has the potential as a medicinal plant, however, until now, it has no economic value and weeds for farmers, especially in palm oil plantations. This plant has not been utilized for commercial purposes as a raw material of herbal medicine because it has a low yield value. Application of green extraction for secondary metabolite extraction of this herbs is expected to be developed and utilized to produce the potential commercial products. The ionic liquid is a green solvent that has the flexibility of ions combination to adjust the physicochemical properties of the target compounds and potential to replace the organic solvents that are flammable, volatile, and toxic. ${ }^{11}$ In addition, the targeted compounds can be improved by considering safety, toxicological, economics, and environmental impact standpoint. ${ }^{12}$ The application of ionic liquid as a green solvent in extraction process performed a non-conventional extraction method such as microwave, supercritical fluid, ultrasonic, countercurrent, and so on. ${ }^{13,14}$ However, some studies have reported the application of ionic liquid-based microwave assisted extraction in extracting secondary metabolites. ${ }^{15-18}$ The target compounds have been successfully increased the yields using an ionic liquid as a solvent, including trans-resveratrol from Poligani cuspidati, ${ }^{17}$ quercetin from Psidium guajava,${ }^{16}$ orientin and vitexin from Trollius chinensis, ${ }^{19}$ flavonoids from Scutellaria baicalensis Georgi, ${ }^{18}$ and diosgenin from Rhizoma dioscoreae. ${ }^{20}$ In previous study, this method has been successfully applied for extracting secondary metabolites in the herbs. ${ }^{15}$ However, the application of 1-butyl3-methyl imidazolium bromide and 1-butyl-3-methyl imidazolium chloride as a green solvent to extracting the polyphenolic content from P. pellucida herbs has not been reported.

The kinds of ionic liquid were used as a green solvent to extraction a polyphenolic constituent from plants among others 1-butyl-3-methyl imidazolium chloride, 1-butyl-3-methyl imidazolium bromide, 1-butyl3-methyl imidazolium dihydrogen phosphate, 1-butyl-3-methyl imidazolium tetrafluoroborate, 1-ethyl-3-methyl imidazolium bromide, 1-hexyl3-methyl imidazolium hydrogen sulfate, and 1-octyl-3-methyl imidazolium bromide. ${ }^{15,16,17,18,19-21}$

Additionally, the use of conventional organic solvents on the secondary metabolites extraction from plants can produce high residual solvent and low efficiency. Therefore, the objective of the study was to explore 
the effectiveness of the IL-MAE methods using the ionic liquid as a green solvent.

\section{METHODS}

\section{Plants Material}

A sample of $P$. pellucida was collected from North Mamuju, West Sulawesi, Indonesia and was identified at the Herbarium Bogoriense, Bogor Botanical Garden, Bogor, West Java, Indonesia. The voucher specimen was deposited at Laboratory of Pharmacognosy-Phytochemistry, Faculty of Pharmacy, Universitas Indonesia, Depok, West Java, Indonesia.

\section{Chemical materials and General Equipment}

The chemicals were used in this study, such as methanol for analysis, aquadest, ethyl acetate, n-hexane were purchased from PT. SmartLab Indonesia, Indonesia. 1-butyl-3-methyl imidazolium bromide ([BMIM] $\mathrm{Br})$ and 1-butyl-3-methyl imidazolium chloride ([BMIM]Cl) were purchased from Shanghai Chen Jie Chemical, China. Folin-Ciolcalteu reagent, sodium carbonate, and gallic acid standard were purchased from Sigma-Aldrich (via PT. Elo Karsa, Indonesia). The equipments were used including Modena Microwave 900 watts (Buono-MV 3002, USA), Rotary evaporators (Buchi, Germany), Vortex mixer (Stuart, Germany), Spectrophotometer UV-VIS (VersaMax ${ }^{\mathrm{TM}}$ ELISA Microplate Reader, USA), Micropipette, and JOEL scanning electron microscope (JSM-5510LV).

\section{Extraction Process}

\section{Conventional extraction method}

The dried powder of samples (3 gram) were macerated with $50 \mathrm{ml} \mathrm{n}$ hexane, allowed to stand for $24 \mathrm{~h}$, filtered and evaporated to obtain a dry extract. Furthermore, the residue was remacerated using ethyl acetate with the same procedure.

\section{Ionic Liquid Based Microwave-Assisted Extraction (IL-MAE) Method}

An ionic liquid based microwave-assisted extraction (IL-MAE) method was used to extracting polyphenolic content based on literature. . $^{15-21}$ Briefly, the dried powder of samples (3 gram) was mixed with an ionic liquid solvent then extracted using an IL-MAE (Modena 900 Watt, with slight modification) which operated under some conditions. The residue and extract solution were separated by filtering using a cotton swab and cooled at room temperature. The obtained extract solution was left for 10 to 12 hours to precipitate the desired extract.

\section{Total Polyphenolic Content Determination}

Determination of the total polyphenolic content was conducted using a microplate reader 96 well method based on literature. ${ }^{22,23,24}$ Briefly, a total of $20 \mu \mathrm{l}(1000 \mathrm{ppm})$ of the extract solution or the standard solution was added to $100 \mu \mathrm{l}$ reagent $25 \%$ Folin-Ciolcalteu solution, homogenized for one minute, and allowed for 4 minutes. Then a $75 \mu$ l sodium carbonate solution was added and homogenized for one minute. Absorbance was measured at a $750 \mathrm{~nm}$ wavelength using a microplate reader 96 well after incubated for 2 hours at room temperature in the dark. Gallic acid solutions $(200,100,50,25$, and $12.5 \mu \mathrm{g} / \mathrm{l}$, respectively) were used as standards and the equation was $\mathrm{Y}=0.023+7.812 \mathrm{X}\left(\mathrm{R}^{2}=0.999\right)$. Where $\mathrm{Y}$ is the yields of total phenolic content, and $\mathrm{X}$ is the concentration of standard or sample. It was applied to determine the total polyphenolic content from the samples.

\section{Extraction Mechanism Analysis}

Analysis of the mechanism extraction was performed with a comparison between morphological of before and after extraction process using
Scanning Electron Microscopy (SEM) based on literature. ${ }^{25,26}$ Briefly, dried powder of $P$. pellucida herb was sown on the carbon plate and was coated with a thin layer of palladium-gold to form a conductive surface. The preparation was examined using scanning electron microscopy at an operating voltage of $20 \mathrm{kV}$ and under high vacuum conditions.

\section{RESULTS}

\section{Extraction Process}

In Table 1, shows the combination of extraction conditions using four factors and three levels with a total of 64 combinations. It was consist of extraction time (10, 15, and 20 minutes), microwave power (90, 270, and 450 Watts), ionic liquid concentration $(0.2,0.7$, and $1.2 \mathrm{~mol} / \mathrm{l})$, and liquid-solid ratio $(10,12$, and $14 \mathrm{ml} / \mathrm{g})$ against the yields of total polyphenolic content.

\section{Determination of Total Polyphenolics}

Table 2 and Table 3, demonstrated the combination effect of extraction condition using [BMIM] $\mathrm{Br}$ and [BMIM]Cl with ionic liquid based microwave assisted extraction method. According to the results in Table 2 was obtained the 10 highest of yields with the combination of extraction condition factors and the best yields (15.734 $\mu \mathrm{g}$ GAE/g) using [BMIM] $\mathrm{Br}$ as a solvent. Whereas, the results in Table 3 was obtained the best yields (18.287 $\mu \mathrm{g} \mathrm{GAE} / \mathrm{g})$ and the 10 highest of yields using [BMIM]Cl. Comparison of efficiency level between an ionic liquid as a green solvent and conventional organic solvent shown in Figure 1.

\section{Extraction Mechanism}

In Figure 2, shows significant physical changes in matrix sample after treatment with different solvents. Based on the result, described the changes of cell wall surface in matrix samples that have been extracted using the IL-MAE compared to the maceration method.

\section{DISCUSSION}

P. pellucida herb is a plant rich in pharmacological properties. However, the plant has not utilized as raw materials for commercial herbal medicines because it constrained by the various factors such as cultivation, standardization, optimal results, optimal extraction methods, and so on. Development of extraction method is one of the factors that play a major role in obtaining the optimum yields. Application of ionic liquid as the green solvent is expected to be a solution in the development of extraction method by considering the green chemistry principles which to be the main objective of this study.

The extraction process was performed using IL-MAE method based on the preliminary research has been reported. ${ }^{15}$ The yields of total polyphenolic content were examined using a microplate reader 96 well-validated methods according to the literature that has been reported by BoboGarcia and his colleague. ${ }^{24}$ The extraction mechanism was analyzed using SEM..$^{25,26}$

The IL-MAE method aims to apply the green chemistry principles in the extraction process of a secondary metabolite from this herbs. The extraction process was conducted based on the previous study.$^{15}$ It was performed using some combinations of the condition factors, including extraction time (minute), microwave power (Watts), ionic liquid concentration $(\mathrm{mol} / \mathrm{l})$, and the liquid-solid ratio $(\mathrm{ml} / \mathrm{g})$ on the yields of total polyphenolics content compared with maceration or conventional method. The highest of yields of total polyphenolics content was obtained from the IL-MAE method using [BMIM]Cl with amount 18.287 $\mu \mathrm{g}$ GAE/g.

The solvent hydrophobicity enhancement has the ability to increase the extraction capability of the targeted secondary metabolite. ${ }^{12}$ The hydro- 
Table 1: Experimental design based on the combination of extraction condition factor using ionic liquid based microwave assisted extraction (IL-MAE).

\begin{tabular}{ccccc}
\hline \multirow{2}{*}{ Extraction condition factors } & Unit & Low & Medium & High \\
\hline Extraction time & Minutes & 10 & 15 & 20 \\
Microwave power & Watts & 90 & 270 & 450 \\
Ionic liquid concentration & $\mathrm{mol} / \mathrm{l}$ & 0.2 & 0.7 & 1.2 \\
Liquid-solid ratio & $\mathrm{ml} / \mathrm{g}$ & 10 & 12 & 14 \\
\hline
\end{tabular}

Table 2: The application of ionic liquid based microwave assisted extraction using 1-buthyl-3-methylimidazolium bromide ([BMIM]Br) as a solvent.

\begin{tabular}{ccccccc}
\hline Run & $\begin{array}{c}\text { Extraction time } \\
\text { (Minute) }\end{array}$ & $\begin{array}{c}\text { Microwave } \\
\text { power (Watts) }\end{array}$ & $\begin{array}{c}\text { lonic liquid } \\
\text { concentration } \\
(\mathrm{mol} / \mathrm{l})\end{array}$ & $\begin{array}{c}\text { Liquid- } \\
\text { solid ration } \\
(\mathrm{ml} / \mathrm{g})\end{array}$ & $\begin{array}{c}\text { Approximately } \\
\text { Absorbance }\end{array}$ & $\begin{array}{c}\text { Total polyphenolic } \\
\text { content } \\
(\mu \mathrm{g} \mathrm{GAE/g)}\end{array}$ \\
\hline 1 & 10 & 270 & 0.7 & 14 & 1.498 & 15.734 \\
2 & 15 & 270 & 0.7 & 12 & 1.289 & 13.508 \\
3 & 15 & 450 & 1.2 & 12 & 1.288 & 13.491 \\
4 & 15 & 90 & 0.7 & 10 & 1.226 & 12.829 \\
5 & 15 & 450 & 0.7 & 14 & 1.183 & 12.374 \\
6 & 15 & 270 & 1.2 & 10 & 1.097 & 11.457 \\
7 & 15 & 90 & 1.2 & 12 & 1.067 & 11.133 \\
8 & 10 & 270 & 0.7 & 10 & 1.033 & 10.778 \\
9 & 15 & 270 & 0.7 & 14 & 0.980 & 10.209 \\
10 & 15 & 450 & 0.7 & 10 & 0.973 & 10.130 \\
\hline
\end{tabular}

Table 3: The application of ionic liquid based microwave assisted extraction using 1-buthyl-3-methylimidazolium chloride ([BMIM]Cl) as a solvent.

\begin{tabular}{|c|c|c|c|c|c|c|}
\hline Run & $\begin{array}{l}\text { Extraction time } \\
\text { (Minute) }\end{array}$ & $\begin{array}{c}\text { Microwave } \\
\text { power (Watts) }\end{array}$ & $\begin{array}{c}\text { Ionic liquid } \\
\text { concentration } \\
\text { (mol/l) }\end{array}$ & $\begin{array}{l}\text { Liquid-solid } \\
\text { ration }(\mathrm{ml} / \mathrm{g})\end{array}$ & $\begin{array}{c}\text { Approximately } \\
\text { Absorbance }\end{array}$ & $\begin{array}{c}\text { Total polyphenolic } \\
\text { content } \\
(\mu \mathrm{g} \mathrm{GAE} / \mathrm{g})\end{array}$ \\
\hline 1 & 15 & 270 & 0.7 & 14 & 1.737 & 18.287 \\
\hline 2 & 15 & 270 & 0.7 & 12 & 1.492 & 15.670 \\
\hline 3 & 15 & 90 & 0.2 & 12 & 1.286 & 13.472 \\
\hline 4 & 15 & 90 & 0.7 & 14 & 1.063 & 11.094 \\
\hline 5 & 10 & 90 & 0.7 & 12 & 1.046 & 10.916 \\
\hline 6 & 10 & 270 & 0.2 & 12 & 1.029 & 10.731 \\
\hline 7 & 20 & 450 & 0.7 & 12 & 1.026 & 10.699 \\
\hline 8 & 10 & 450 & 0.7 & 12 & 1.012 & 10.546 \\
\hline 9 & 15 & 90 & 0.7 & 10 & 0.997 & 10.394 \\
\hline 10 & 20 & 270 & 0.7 & 14 & 0.995 & 10.372 \\
\hline
\end{tabular}

phobicity of both ionic liquids were used in this study, namely [BMIM] $\mathrm{Br}<[\mathrm{BMIM}] \mathrm{Cl},{ }^{27}$ respectively. Moreover, the hydrogen bonding capability of ionic liquids was a factor affecting the extraction process with considering anions..$^{28}$ Based on the results, application of ionic liquids as a green solvent was more efficient than conventional organic solvents. Some studies have reported the success of ionic liquids in extracting polyphenolic compounds from natural products. ${ }^{15,16,17,18} 19-21$

The SEM analysis aimed to determine the surface changes and cell wall matrix (sample) caused by the extraction process either by maceration or ILMAE method. Some studies have reported the effect of surface changes and cell wall matrix by using ionic liquid solvents. ${ }^{18,29,28}$ The microstruc- tures of the samples were clearly apparent changes after extraction using IL-MAE compared with conventional methods. The efficiency of ILMAE extraction could be attributed to the ability of the microwave to cause damage to the cell wall surface, thus facilitate the release of the solute in the sample matrix into solution (solvent). ${ }^{12}$ Furthermore, the changes have a correlation with the yields of total polyphenol content was produced by the maceration and the IL-MAE method. The efficiency of the IL-MAE method was much higher than the maceration method that caused damage to the cell wall surface of the sample matrix.

The role of ionic liquids in the extraction process of medicinal plants is not only limited to the increased interaction between solutes and 


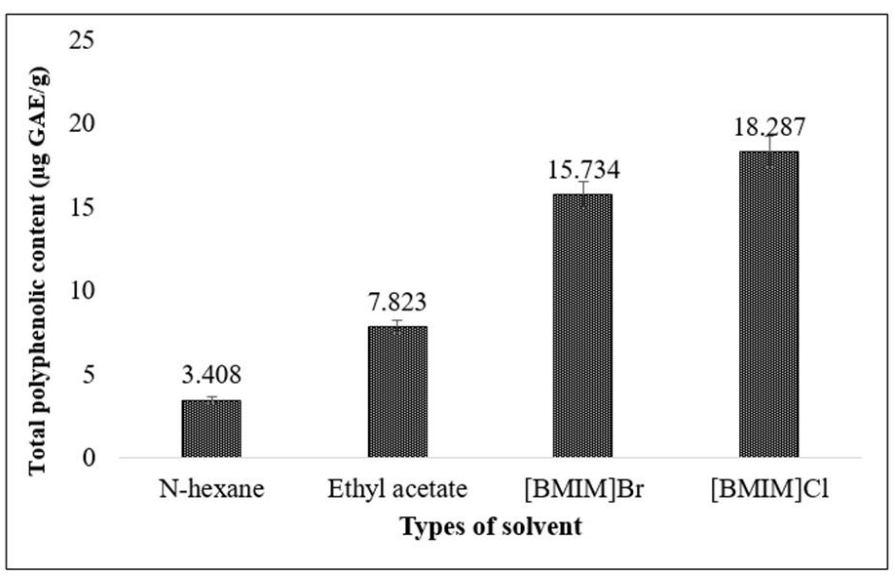

Figure 1: The yields of total polyphenolics content from P. pellucida herbs using ionic liquid and conventional organic solvent

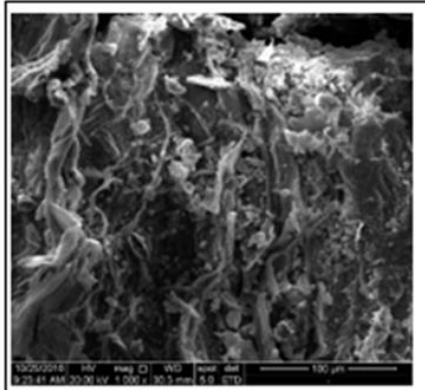

(A1)

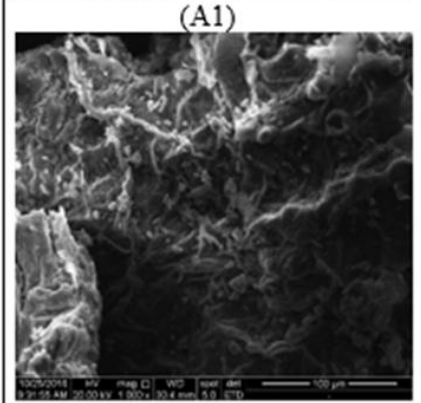

(B1)

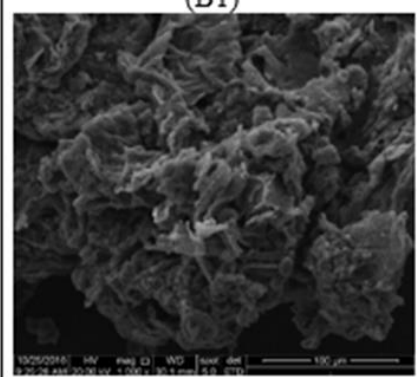

(C1)

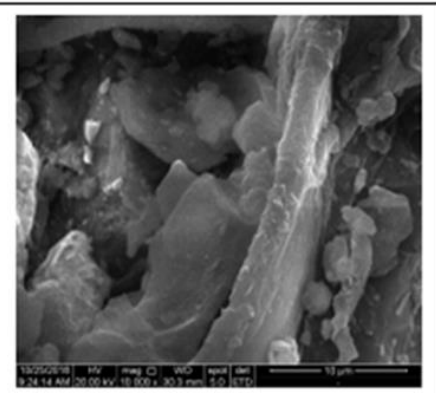

(A2)

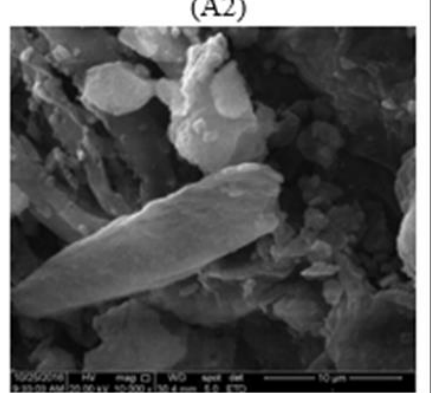

(B2)

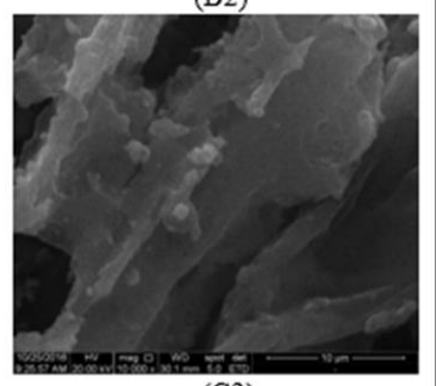

$(\mathrm{C} 2)$
Figure 2: Scanning electron micrographs of $P$. pellucida herb samples: (A) Untreated P. pellucida sample ( $\mathrm{A} 1$ is the $100 \mu \mathrm{m}$ image, $\mathrm{A} 2$ is the $10 \mu \mathrm{m}$ image); (B) after maceration (B1 is the $100 \mu \mathrm{m}$ image, $\mathrm{B} 2$ is the $10 \mu \mathrm{m}$ image); and (C) after IL-MAE (C1 is the $100 \mu \mathrm{m}$ image, $\mathrm{C} 2$ is the $10 \mu \mathrm{m}$ image).

solvents but may also be associated with the solvents used which cause modification of changes in the interaction of the permeability of the plant matrix. ${ }^{30}$ Therefore, the characteristic of ionic liquids to influence the conformation of carbohydrates through hydrogen bonding and can be considered as viable substituents to be value-added solvents when compared to classical extraction methods. While the use of microwaveassisted extraction is known to cause a cells tissue interference by a microwave irradiation will contribute additionally to facilitate the overall process.

\section{CONCLUSION}

Based on the above results, the use of ionic liquid as a green solvent ([BMIM]Br and [BMIM]Cl) can be applied to extracting polyphenolic compounds from $P$. pellucida herb. The extraction of a secondary metabolite targeted from this herb becomes more efficient, easy, and rapid. For further research, it is necessary to optimize the extraction methods to obtain target secondary metabolites.

\section{ACKNOWLEDGEMENT}

This study was supported by Ministry of Research, Technology, and Higher Education, the Republic of Indonesia and Lembaga Penelitian dan Pengabdian Masyarakat Universitas Mulawarman (LP2M UNMUL) via a grant "Hibah Disertasi Doktor 2016-2017 (No. 396/UN17.41/ KL/2017),"

\section{CONFLICT OF INTEREST}

All author declared that have no conflict of interest

\section{ABBREVIATION USED}

IL-MAE: ionic liquid based microwave assisted extraction; [BMIM]Br: 1-buthyl-3-methylimidazolium bromide; [BMIM]Cl: 1-buthyl-3-methylimidazolium chloride; SEM: scanning electron microscopy; GAE: gallic acid equivalent; P. pellucida; Peperomia pellucida.

\section{REFERENCES}

1. Heyne K. The Useful Indonesian Plants. Third Edition. Research and Development Agency, Ministry of Forestry, Indonesia: Jakarta; 2007. 1-462 p. (In Bahasa)

2. Hamzah RU, Odetola AA, Erukainure OL, Oyagbemi AA. Peperomia pellucida in diets modulates hyperglycemia, oxidative stress, and dyslipidemia in diabetic rats. J Acute Dis. 2012;1(2):135-40. https://doi.org/10.1016/S2221-6189(13)60031-1

3. Arrigoni-Blank MF, Dmitrieva EG, Franzotti EM, Antoniolli AR, Andrade MR, Marchioro M. Anti-inflammatory and analgesic activity of Peperomia pellucida (L.) HBK (Piperaceae). J Ethnopharmacol. 2004;91(2):215-8. https://doi. org/10.1016/j.jep.2003.12.030

4. Kurniawan A, Saputri FC, Ahmad I, Mun'im A. Isolation of angiotensin converting enzyme (ACE) inhibitory activity quercetin from Peperomia pellucida. Int J PharmTech Res. 2016;9(7):115-21.

5. Majumder P, Abraham P, Satya V. Ethno-medicinal, phytochemical, and pharmacological review of an amazing medicinal herb Peperomia pellucida (L.) HBK. Res J Pharm Biol Chem Sci. 2011;2(4):358-64.

6. Susilawati $Y$, Nugraha R, Muhtadi A, Soetardjo S, Supratman U. (S)-2-Methyl2-(4-methylpent-3-enyl)-6-(propan-2-ylidene)-3,4,6,7-tetrahydropyrano[4,3-g] chromen-9(2H)-one. Molbank. 2015;1-6. https://doi.org/10.3390/M855

7. Rojas-Martínez R, Arrieta J, Cruz-Antonio L, Arrieta-Baez D, Velázquez-Méndez AM, Sánchez-Mendoza ME. Dillapiole, isolated from Peperomia pellucida, shows gastroprotector activity against ethanol-induced gastric lesions in Wistar rats. Molecules. 2013;18(9):11327-37. https://doi.org/10.3390/molecules180911327

8. Khan A, Rahman M, Islam S. Isolation and bioactivity of a xanthone glycoside from Peperomia pellucida. Life Sci Med Res. 2010;1-10.

9. Xu S, Li N, Ning MM, Zhou CH, Yang QR, Wang MW. Bioactive compounds from Peperomia pellucida. J Nat Prod. 2006;69(2):247-50. https://doi.org/10.1021/ np050457s

10. Bayma JDC, Arruda MSP, Müller AH, Arruda AC, Canto WC. A dimeric ArC2 compound from Peperomia pellucida. Phytochemistry. 2000;55(7):779-82. https://doi.org/10.1016/S0031-9422(00)00224-7

11. Jessop PG, Jessop D, Fu D, Phan L. Solvatochromic parameters for solvents of interest in green chemistry. Green Chem. 2012;14(5):1245-59. https://doi. org/10.1039/c2gc16670d

12. Chemat F, Vian MA. Green Chemistry and Sustainable Technology: Alternative Solvents for Natural Products Extraction. Heidelberg, New York, Dordrecht, London: Springer US; 2014.

13. Chemat F, Vian MA, Cravotto G. Green extraction of natural products: Concept 
and principles. Int J Mol Sci. 2012;13(7):8615-27. https://doi.org/10.3390/ ijms13078615. PMID: 22942724

14. Khoddami A, Wilkes $M$, Roberts T. Techniques for analysis of plant phenolic compounds. Molecules. 2013;18(3):2328-75. https://doi.org/10.3390/molecules 18022328

15. Ahmad I, Yanuar A, Mulia K, Mun'im A. Application of ionic liquid based microwave-assisted extraction of the secondary metabolite from Peperomia pellucida (L) Kunth. Pharmacogn J. 2017;9(2):227-34. https://doi.org/10.5530/pj.2017.2.38

16. Du FY, Xiao XH, Luo XJ, Li GK. Application of ionic liquids in the microwaveassisted extraction of polyphenolic compounds from medicinal plants. Talanta. 2009;78:1177-84. https://doi.org/10.1016/j.talanta.2009.01.040. PMID: 19269490

17. Du FY, Xiao XH, Li GK. Application of ionic liquids in the microwave-assisted extraction of trans-resveratrol from rhizoma Polygoni cuspidati. J Chromatogr A. 2007 Jan;1140(1-2):56-62. https://doi.org/10.1016/j.chroma.2006.11.049. PMID: 17141255

18. Zhang Q, Zhao SH, Chen J, Zhang LW. Application of ionic liquid-based microwave-assisted extraction of flavonoids from Scutellaria baicalensis Georgi. J Chromatogr B. 2015;1002:411-7. https://doi.org/10.1016/j.jchromb.2015.08.021

19. Chen F, Zhang Q, Mo K, Fei S, Gu H, Yang L. Optimization of ionic liquid-based homogenate extraction of orientin and vitexin from the flowers of Trollius chinensis and its application on a pilot scale. Sep Purif Technol. 2017;175:147-57. http://dx.doi.org/10.1016/j.seppur.2016.10.062

20. Yan W, Ji L, Hang S, Shun Y. New ionic liquid-based preparative method for diosgenin from Rhizoma dioscoreae nipponicae. Pharmacogn Mag. 2013;9(35):250-4. https://doi.org/10.4103/0973-1296.113282. PMID: 23930010

21. LuY, MaW, Hu R, Dai X, Pan Y. Ionic liquid-based microwave-assisted extraction of phenolic alkaloids from the medicinal plant Nelumbo nucifera Gaertn. J Chromatogr A. 2008;1208(1-2):42-6. https://doi.org/10.1016/j.chroma.2008.08.070. PMID: 18774575

22. Asowata-Ayodele AM, Otunola GA, Afolayan AJ. Assessment of the polyphenolic content, free radical scavenging, anti-inflammatory, and antimicrobial activities of acetone and aqueous extracts of Lippia javanica (Burm.F.) spreng. Pharma- cogn Mag. 2016;12(Suppl 3):353-62. https://doi.org/10.4103/0973-1296.185770

23. Christapher PV, Parasuraman $S$, Raj PV, Saghir SAM, Asmawi MZ, Vikneswaran M. Influence of extracting solvent on pharmacological activity and cytotoxicity of Polygonum minus, a commonly consumed herb in Southeast Asia. Pharmacogn Mag. 2016;12(47):424-30. https://doi.org/10.4103/0973-1296.191451

24. Bobo-García G, Davidov-Pardo G, Arroqui C, Marín-Arroyo MR, Navarro M. Intra-laboratory validation of microplate methods for total phenolic content and antioxidant activity of polyphenolic extracts, and comparison with conventional spectrophotometric methods. J Sci Food Agric. 2014;95(1):204-9. https://doi. org/10.1002/jsfa.6706

25. Khademi A, Saatchi M, Shokouhi MM, Baghaei B. Scanning electron microscopic evaluation of residual smear layer following preparation of curved root canals using hand instrumentation or two engine-driven systems. Iran Endod J. 2015;10(4):236-9. https://doi.org/10.7508/iej.2015.04.005. PMID: 26523137

26. Krishnan RY, Chandran MN, Vadivel V, Rajan KS. Insights on the influence of microwave irradiation on the extraction of flavonoids from Terminalia chebula. Sep Purif Technol. 2016;170:224-33. https://doi.org/10.1016/j.seppur. 2016.06.039

27. Tan Z, YiY, Wang H, Zhou W, Wang C, McPhee DJ. Extraction, preconcentration, and isolation of flavonoids from Apocynum venetum $L$. leaves using ionic liquidbased ultrasonic-assisted extraction coupled with an aqueous biphasic system. Molecules. 2016;21(3):262-73. https://doi.org/10.3390/molecules21030262

28. Cláudio AFM, Marques CFC, Boal-Palheiros I, Freire MG, Coutinho JAP Development of back-extraction and recyclability routes for ionic-liquid-based aqueous two-phase systems. Green Chem. 2014;16(1):259-68. https://doi. org/10.1039/C3GC41999A

29. Liu F, Wang D, Liu W, Wang $X$, Bai A, Huang L. Ionic liquid-based ultrahigh pressure extraction of five tanshinones from Salvia miltiorrhiza Bunge. Sep Purif Technol. 2013;110:86-92. https://doi.org/10.1016/j.seppur.2013.03.012

30. Ding $X, L i ~ L$, Wang $Y$, Chen J, Huang $Y, X u K$. Design of guanidinium ionic liquid based microwave-assisted extraction for the efficient extraction of Praeruptorin A from Radix peucedani. J Sep Sci. 2014;37(23):3539-47. https:// doi.org/10.1002/jssc.201400828

Article History: Submission Date : 30-04-2017 ; Revised Date : 15-07-2017; Acceptance Date : 19-08-2017.

Cite this article: Ahmad I, Yanuar A, Mulia K, Mun'im A. Application of lonic Liquid as a Green Solvent for Polyphenolics Content Extraction of Peperomia Pellucida (L) Kunth Herb. J Young Pharm. 2017;9(4):486-90 